\title{
Storage fungi of cabbage and their control
}

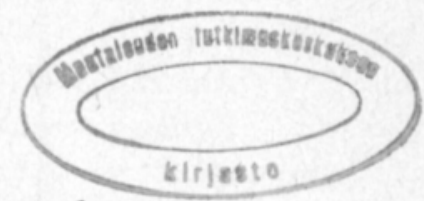

\author{
RISTO TAHVONEN
}

Department of Plant Patbology, University of Helsinki, SF-00710 Helsinki 71, Finland

\begin{abstract}
Botrytis cinerea Pers. ex Fr. was found in $40-100 \%$, in most cases $60-80 \%$, of the stored cabbages examined during $1975-80$. The correlation between the B. cinerea- $\%$ and the trimming losses was highly significant when storage lasted for more than 5 months. The trimming losses in infected cabbage lots were $30-50 \%$, while in healthy lots they were only $10-20 \%$. The numbers of $B$. cinerea remained constant on the same lots, irrespective of the duration of storage. The fungus caused a considerable amount of spoilage at rather low storage temperatures of $-0.5-0^{\circ} \mathrm{C}$. Alternaria brassicicola (Schw.) Wiltshire, Plenodomus lingam (Tode ex Fr.) Höhnel, Typbula brassicae (Berg. ex Fr.) Vang, Wberzelinia sclerotiorum (Lib.) Korf \& Dumont, and an otherwise unidentified fungus, which presumably belonged to the Basidiomycetes and was only found growing on living cabbages, were present in small numbers or else were significant pathogens in individual stores in certain years only. Spraying with benomyl or thiophanatemethyl one or two weeks before harvesting decreased to a highly significant degree the numbers of $B$. cinerea on the cabbages, the commercial quality increasing by $8-25$ $\%$. Spraying during the growing season did not affect the numbers of any of the other storage pathogens.
\end{abstract}

\section{Introduction}

White cabbage comes second to carrot in its importance as a field vegetable in Finland, the area under cultivation having increased from 600 ha halfway through the 1970 's, to about 1000 ha by the end of the decade. The amount of cabbages which are stored has increased correspondingly from about 3000 tons to 9000 tons. The capacity of the vegetable stores in use by the end of the 70's was about $180000 \mathrm{~m}^{3}$, almost half of them being refrigerated $0^{\circ} \mathrm{C}$ stores (YLÄTALO 1980).

The effect of cultivation and storage conditions on the storability of white cabbage has been extensively studied in Finland (SUHONEN 1969). However, no studies have been carried out on the storage pathogens of cabbage and their importance.

Botrytis cinerea Pers. ex Fr. is considered in the literature to be either a significant (WALKER et al. 1958, ELLIS and WALLER 1974) or else the most important agent causing losses during storage (STRUC and CRUTZ 1972, BROWN et al. 1975, BOCHOW et al. 1976, LOCHART 1976, KEAR et al. 1977, SEIDEL and BARESEL 1978). The losses can be as high as about $25-40 \%$ of the stored crop (YODER and WHALEN 1975, KEAR et al. 1977). Other storage pathogens 
of cabbage, which are important in cases where the harvesting conditions are warm and damp or in stores other than refrigerated ones at $0^{\circ} \mathrm{C}$, are as follows: Alternaria spp. (BROWN et al. 1975, GEESON and ROBINSON 1975, KEAR et al. 1977), Fusarium spp. (GEESON and ROBINSON 1975), Phytophthora porri Foister (SEMB 1968, GEESON 1976), Plenodomus lingam (Tode ex Fr.) Höhnel (HENDERSON 1918), Rhizoctonia solani Kühn (WELLMAN 1932, WALKER et al. 1958, ADAIR 1971), Whetzelinia sclerotiorum (Lib.) Korf and Dumont (LIRO 1924, WALKER et al. 1958, ADAIR 1971) and Typhula brassicae (Berg. ex Fr.) Vang (LIRO 1924).

However, most of the above pathogens are not capable of growing in stores refrigerated to $0^{\circ} \mathrm{C}$ and hence control measures aimed directly at them are not necessary. $B$. cinerea cannot be controlled by means of storage conditions because it is able to grow at temperatures as low as $-2^{\circ} \mathrm{C}$ (DOMSCH and GAMS 1970) and at very low oxygen levels (FOLLSTAD 1966, ADAIR 1971). Although treatment with fungicides while the cabbages are being placed in storage or during storage has given good results in the control of $B$. cinerea (VOGEL and NEUBERT 1964, BROWN et al. 1975, KEAR et al. 1977, SEIDEL and BARESEL 1978, GEESON and BROWNE 1979), this method cannot be used in practice owing to the presence of residues of the fungicide in the marketed product.

The aim of this study is to survey the most common and most important storage pathogens of white and red cabbage in Finland and to study their biology and the possibilities of controlling them during the growing season by means of fungicides sprayed on the crop before harvesting.

\section{Material and methods}

Determination of the pathogenic fungi, their abundance and importance

The fungi present on cabbages from 8 different stores in the Turku, Kangasala and Jyväskylä areas were studied at the end of the storage period, March-April, in 1975, 1976 and 1977. In addition, the fungi were examined at the end of the storage period in experiments carried out in Viikki, Kangasala and Jyväskylä during the period 1976-80. These experiments are described in detail later on. During the first two years, samples were taken from all diseased cabbages in cases where it was not possible to identify the pathogen at the site. Botrytis cinerea and Whetzelinia sclerotiorum were easy to identify. In other years, a stereo-microscope was used in the field determinations, thus making it possible to identify a number other pathogens. In all uncertain cases, a small sample was removed from infected parts of the plants, placed on moist filter paper in a petri dish and slides prepared from the samples in the laboratory for examination under a light microscope. When necessary, storage of the samples was continued at $+5^{\circ} \mathrm{C}$ and small pieces removed from the healthy and infected tissue and incubated on PDA medium (Difco) for the isolation and identification of the fungus.

Apart from the measurements made in 1975 and 1976, the abundance of the different fungi on the cabbages was estimated using the scale $0-5$, where $0=$ healthy, $1=$ presence of the fungus without any extensive damage, $2=<1 / 8,3=$ 
$1 / 8-1 / 4,4=1 / 4-1 / 2$ and $5=>1 / 2$ of the surface of the cabbages covered by the fungus and subsequent damage caused by the fungus.

In addition to the degree of fungal infection, the weight of the cabbages when they were placed in the stores in the autumn (A), their weight when they were removed from the stores (B) and the weight after cleaning them ready for sale (C) were determined during the experiments. These measurements were used to determine the evaporation losses $(\mathrm{A}-\mathrm{B})$ the cleaning loss $-\%\left({ }^{\mathrm{B}} \overline{\mathrm{B}} \mathrm{C} \cdot 100\right)$ and the marketability $-\%\left(\frac{C}{A} \cdot 100\right)$. However, the evaporation loss was not used in calculating the results because it was not correlated with the degree of fungal infection. The magnitude of the evaporation loss when the cleaning loss- $\%$ is given the value 0 can be seen in Fig. 1 . Since there was extremely high correlation between the marketability $\%$ and the cleaning losses (Fig. 1), no weight determinations were carried out at the stores in Kangasala and Jyväskylä in the autumn owing to the fact that it was very difficult in practice to weigh boxes weighing between $200-300 \mathrm{~kg}$.

In Viikki, 8-15 medium-sized cabbages were taken at each sampling. In the other experiments a sample of 20 cabbages was taken from each box. The experiments were always repeated with four replications. When the degree of fungus infection was being studied in the different stores, at least 40 cabbages were always taken from different parts of the stores.

\section{Cultivation and storage conditions}

The cabbages were grown using the techniques and fertilization levels commonly in use in Finland (SUHONEN 1980). Containerised seedlings were planted in the first or second week of June and the crop harvested during the first or second week of October. The storage periods are presented in Tables 1 and 2. The white cabbage variety, Faales bluetip, was used in all the experi ents except in Jyväskylä, where half-height Amager was used. The red cabbage variety was Haco W. The weather conditions during the different growing periods were normal except for 1977, when the autumn was wetter than normal.

The cabbage stores (6) in the Turku area were, apart from one of them, induced draught stores. All the other stores were mechanically refrigerated. The temperature used in trial storage at Viikki was $0-+2^{\circ} \mathrm{C}\left(+1^{\circ} \mathrm{C}\right)$, at Kangasala $0-+0,5^{\circ} \mathrm{C}$ $\left(+0^{\circ} \mathrm{C}\right)$ and in Jyväskylä $-0,5-0^{\circ} \mathrm{C}\left(-0^{\circ} \mathrm{C}\right)$.

The relative humidity of the stores at Kangasala and Jyväskylä was 96-98 \% and the cabbages were stored in the type of $1 \mathrm{~m}^{3}$ boxes commonly used by growers. The relative humidity of the store at Viikki was $94-96 \%$. The cabbages were initially stored individually in net bags, but this was discontinued in favour of perforated plastic sheeting $(\emptyset=1 \mathrm{~cm}, 15 \times 15 \mathrm{~cm})$, starting in 1977 , owing to the fact that the air in the stores was found to be too dry. It was not possible to use large boxes in Viikki owing to the limited size of the store and lack of suitable handling equipment.

Spraying during the growing season

The plants were sprayed in the field with different fungicides before harvesting in order to prevent storage pathogens being introduced into the stores along with the cabbages. The chemicals and the application times used in different years are 

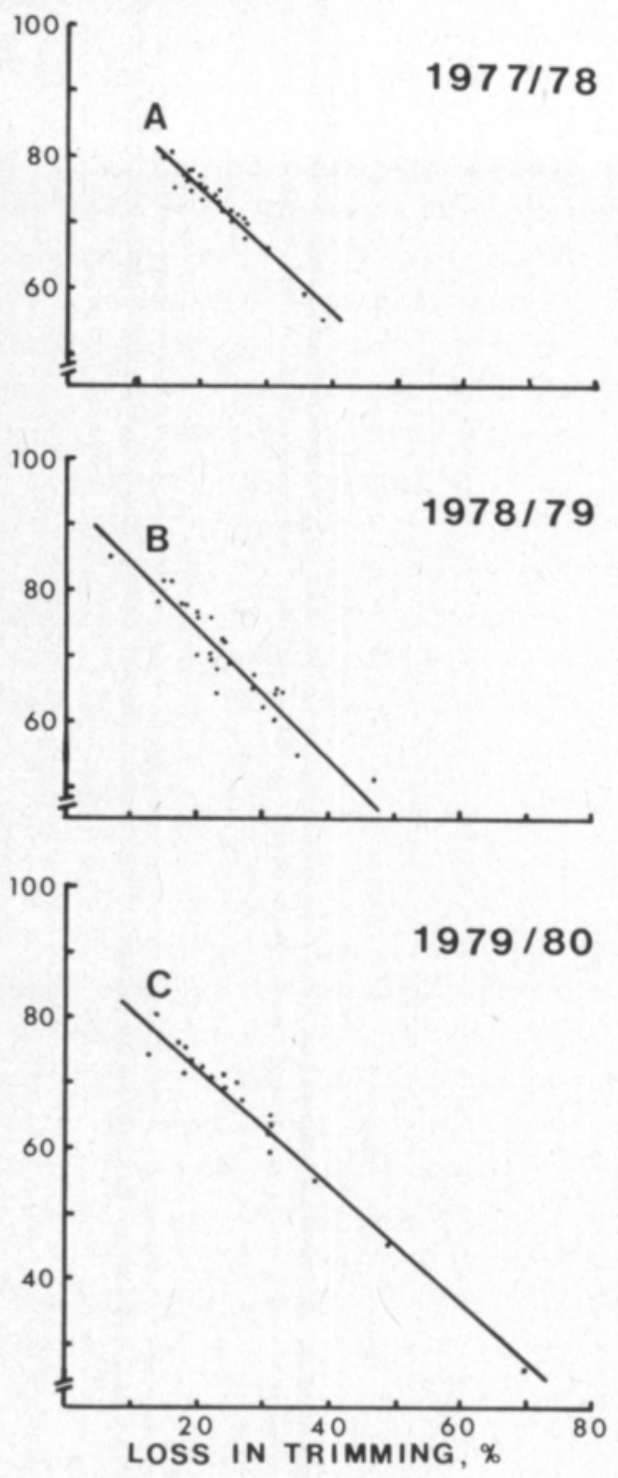

Fig. 1. Correlation between the merchantability and trimming losses of white cabbages stored at $1^{\circ}$ $C$ in different years.
A: $y=-0.932 x+94.08, r=0.96^{x x x}$
B: $y=-1.014 x+94.53, r=0.95^{x x x}$
C: $y=-0.897 x+89.60, r=0.97^{x x x}$

presented in Table 1. Benomyl (Benlate, $50 \%$ ) was applied at a dosage of 0.6 $\mathrm{kg} / \mathrm{ha}$, thiophanatemethyl (Topsin M, $70 \%$ ) at $0.98 \mathrm{~kg} / \mathrm{ha}$, tolylfluanide (Euparen $\mathrm{M}, 50 \%$ ) at $1.25 \mathrm{~kg} / \mathrm{ha}$ and captaphol (Difolatan, $80 \%$ ) at $0.75 \mathrm{~kg} / \mathrm{ha}$. The plants were given 20001 water/ha at Viiki during 1975-77 and in the other experiments $1000 \mathrm{l} / \mathrm{ha}$. Different amounts of liquid were tested in 1979 (see Table 2) in order to determine the effect on the control result. The amounts of active ingredients were kept, however, constant.

The presence of fungicide residues on the cabbages was checked in 1977 and 1978 at the State Institute for Agricultural Chemistry. 
The growth of Botrytis cinerea, Plenodomus lingam and Whetzelinia sclerotionum on white cabbages was tested in 1976 at temperatures of $-0^{\circ} \mathrm{C},+5^{\circ} \mathrm{C}$ and $+20^{\circ} \mathrm{C}$. Cabbage samples were taken immediately after harvesting. A section of cabbage leaves, about $1-2 \mathrm{~cm}$-thick, was taken from the outermost leaves of the cabbage heads and inoculated with a piece of agar taken from a pure culture of the fungus in question. At the same time, the surface of the leaf tissue was punctured with a needle. The samples were incubated on moist filter paper in a container covered with plastic film. One purpose of this experiment was to determine the effect of sprayings carried out in the field on the growth of the fungi during storage. As the treatments no longer had any effect at this stage, the results are only presented as a function of the correlation between time and fungal damage at different temperatures.

\section{Statistical treatment}

The results of the control experiments have been tested by means of analysis of variance and by calculating $\mathrm{LSD}_{\mathrm{t}} 0.05$. The LSD value is presented in Table 1 only in those cases where the $\mathrm{F}$ value is greater than the value representing significance at the $5 \%$ risk level. The correlation between the cleaning loss $-\%$ and marketability- $\%$, the Botrytis- $\%$ and Botrytis abundance, and between the Botrytis abundance and cleaning loss $-\%$ have been depicted by means of a straight line, $y=b x+a$, or curve, $\mathrm{y}=\alpha$ e $\beta$, and the significance has been tested by means of the coefficient of correlation. The means and the standard errors are calculated for the decay measuring of the temperature tests and the t-test is used, if necessary, in testing the difference between the disease percentage of two storage times.

\section{Results}

\subsection{Fungi causing storage damage}

\subsubsection{Botrytis cinerea Pers. ex Fr.}

B. cinerea initially produced soft, watery spots with light grey mycelium on the surface, on the outermost leaves of the cabbages. At the beginning of the storage period there was frequently a dark or even black band along the border of the healthy tissue and the extending infected area. By the end of the storage period, in March-April, the fungus had spread rapidly over the whole surface of the cabbage head, penetrated into the inner layers of the cabbage and covered the surface of the cabbage with a dense, ash-grey layer of conidiophores (Fig. 2). The infected parts turned soft and watery, although they retained their overall shape. In many cases the heads were completely spoilt.

B. cinerea was a very common storage pathogen on the cabbages. The pathogen was found on $40-100 \%$ of the cabbages in all the stores, usually infecting $60-80$ $\%$ of the cabbages. In the Turku area, where the most usual variety grown was 'High Amager', the B. cinerea-\% in the stored cabbages was lower (3-75\%) than in other areas where the varieties 'Faales Bluetip' and 'Half-height Amager' were grown. 


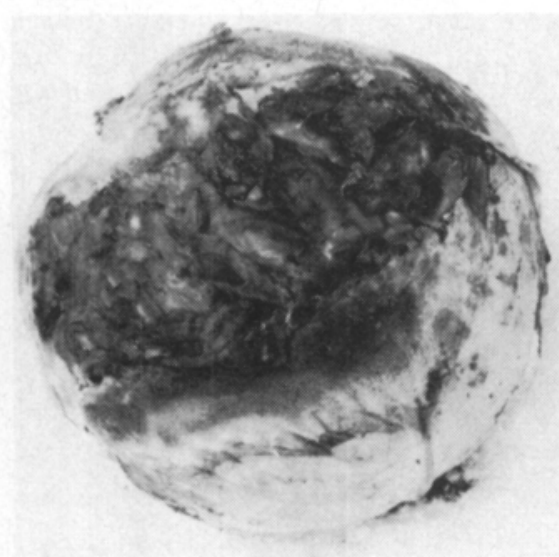

Fig. 2. Botrytis cinerea on the surface of a cabbage head.

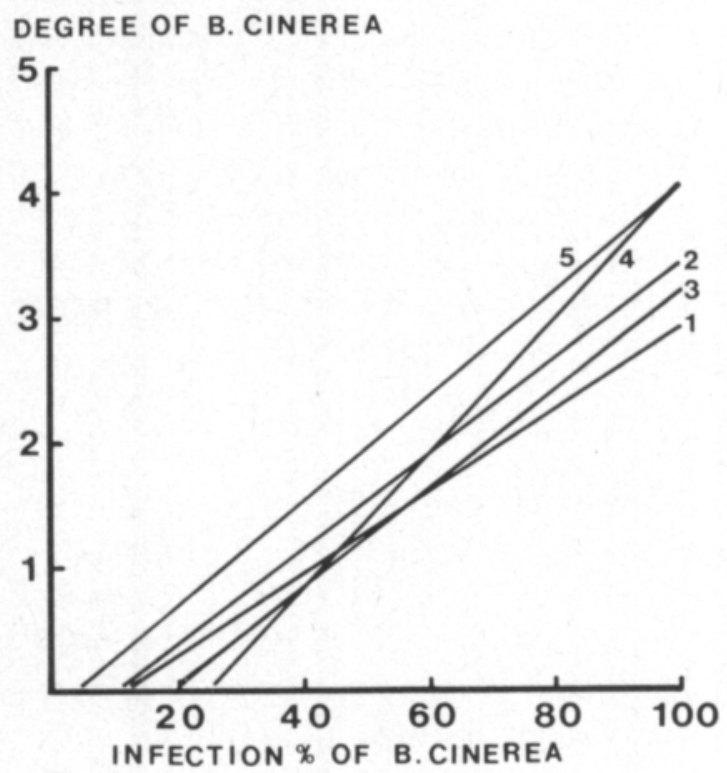

Fig. 3. Correletion between the Botrytis cinerea abundance and $B$. cinerea infection- $\%$.

1. 5.5 months at $+0^{\circ} \mathrm{C}$ in $1976 / 77$, $\mathrm{y}=0.033 \mathrm{x}-0.365, \mathrm{r}=0.98^{\mathrm{xxx}}$

2. 6.5 months at $+0^{\circ} \mathrm{C}$ in $1976 / 77$, $y=0.039 x-0.486, r=0.96^{x x x}$

3. 3.5 months at $+1^{\circ} \mathrm{C}$ in $1976 / 77$, $y=0.039 x-0.72, \quad r=0.95^{x x x}$

4. 5.5 months at $+1^{\circ} \mathrm{C}$ in $1976 / 77$, $y=0.054 x-1.34, \quad r=0.94^{x x x}$

5. 5.8 months at $+1^{\circ} \mathrm{C}$ in $1979 / 80$, $y=0.0418 x-0.12, \quad r=0.97^{x x x}$

There was very high positive correlation between the $B$. cinerea- $\%$ and the mean abundance of $B$. cinerea on the cabbages. The coefficient of correlation varied in the different experiments from 0.96 to 0.98 (Fig. 3). For this reason, the occurrence of $B$. cinerea in the different experiments has been presented using the abundance scale $0-5$ only. These values can be converted if desired into mean percentage levels by using the data given in Fig. 3.

$B$. cinerea was clearly visible on the surface of the cabbages already after only two or three months storage. The $B$. cinerea- $\%$ was not significantly increased $(t=$ 1.27 ) in the different experiments carried out during winter $1976 / 77$ when a change was made from a short storage period to a long one. The fungus initially grew on the outermost leaves of the cabbages only and hence did not produce any considerable storage losses. However, after the fifth or sixth month of storage very 

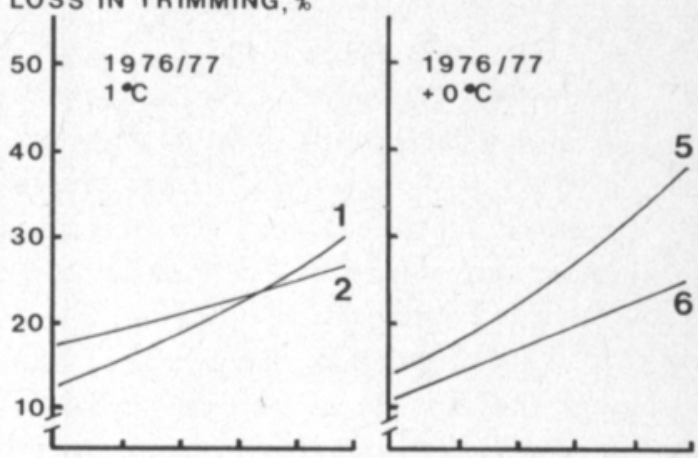

Fig. 4. Effect of $B$. cinerea abundance on the trimming losses of white cabbage.

1. 5.5 months, $y=11.9 e^{0.18 x}, r=0.72^{x x x}$

2. 3.5 months, $y=16.8 e^{0.10 x}, r=0.36^{x}$

3. 3.5 months, $y=21.0 e^{0.11 x}, r=0.62^{x x x}$

4. 1.6 months, $y=3.5 x+12.6, r=0.72^{x x x}$

5. 6.5 months, $y=13.5 e^{0.21 x}, r=0.70^{x x x}$

6. 5.5 months, $y=2.7 x+10.8, r=0.72^{x x x}$

7. 5.8 months, $y=7.6 x+16.9, r=0.82^{x x x}$
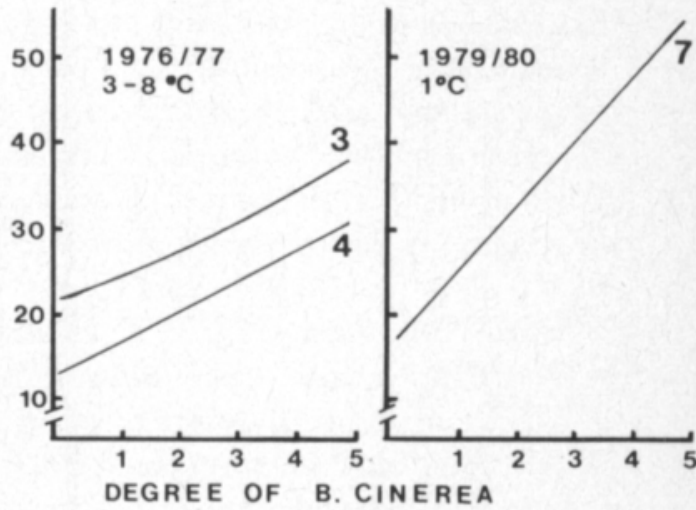

rapid spoilage started to occur. This is clearly demonstrated in Fig. 8 when comparing the results for 5.5 and 6.5 months. Severe spoilage occurred in the aerated stores already after three months storage.

There was very high positive correlation $(r=0.36-0.82$, Fig. 4) between the numbers of $B$. cinerea and the cleaning loss $\%$. The lowest correlation coefficient $(0.36)$ was found with a short storage period ( 3.5 months). In this case the damage was not extensive and the fungus had not penetrated into the lower cabbage leaves. The cleaning losses of severely damaged cabbages approached $30-50 \%$, the losses for corresponding healthy cabbages being only $10-20 \%$ (Fig. 4, Table 1).

$B$. cinerea grew and caused damage even in the cold stores at the lowest temperatures (Table 1). When temperature trials were carried out, the fungus was found to be capable of damaging cabbage tissue at all the temperatures tested. At a low temperature of $0^{\circ} \mathrm{C}$, and also at $20^{\circ} \mathrm{C}$, the damage spread initially rather slowly, although later on it speeded up. The rate of spoilage at a low temperature of $+5^{\circ} \mathrm{C}$ was initially faster than at any other temperature (Fig. 5).

\subsubsection{Other storage pathogens}

Alternaria brassicicola Wiltshire was found in all of the stores of the cabbagegrowing areas studied and also in all the field trials which were carried out. However, the infection- $\%$ in all the stores was always below $2 \%$. As the fungus produced dark moldy spots on the outermost leaves only, which are normally removed when they are being cleaned ready for sale, the fungus did not cause any significant storage losses. 
Plenodomus lingam (Tode ex Fr.) Höhnel was found every year in the cabbage stores at levels of less than $5 \%$, apart from 1977/78 when it varied from $5-15 \%$ in the different stores. Owing to the fact that it occurred at low levels only and also because it caused only slight damage, which in most cases affected only one to three of the outermost layers of leaves, the fungus did not cause any significant storage losses. P. lingam was found to grow on infected cabbages at temperatures of $5^{\circ} \mathrm{C}$ or more, destroying $60-80 \%$ of the test cabbages after 8 weeks, but it grew only slowly on cabbages at $0^{\circ} \mathrm{C}$ (Fig. 5 ).

Typhula brassicae (Berg. ex Fr.) Vang produced a watery, soft rot on cabbage, which initially spread over the outermost leaves (Fig. 6a). By the end of the storage period, in April, the fungus had frequently destroyed the cabbage heads completely, the cabbage turning into a soft, porridge-like mass. Round sclerotia, $0.5-2 \mathrm{~mm}$ in diameter, which were initially light coloured, later brown and finally black, grew on the surface and inside the destroyed tissue (Fig. 6b). Sterile basidiocarps grew from the sclerotia at $20^{\circ} \mathrm{C}$ in the dark. The basidiocarps were fertile, $1-2 \mathrm{~cm}$-long, when grown at $10^{\circ} \mathrm{C}$ in the light. The thickness of the basidium was $4.6 \mu(3-5.5 \mu)$, the length of the sterigmata $4.6 \mu(3-7 \mu)$ and the size of the basidiospores $3.1 \times 9.2 \mu(1.5-4.4 \times 7-14 \mu)$.

Apart from in 1977/78, T. brassicae was rarely found and always at levels below $10 \%$, in most cases below $2 \%$. However, the fungus was abundant in $1977 / 78$ : in $16 \%$ of the cabbage in the experiments in Viikki, $8 \%$ in Jyväskylä and $37 \%$ in Kangasala. In most cases the damage caused by this fungus was insignificant because only the outermost leaves were affected by March, these leaves normally being removed prior to marketing. The fungus only started to completely destroy cabbages by April, after 7 months storage.

Whetzelinia sclerotiorum (Lib) Korf \& Dumont occurred as an occasional pathogen in stored cabbages, being found at levels below $1 \%$ in two stores Kangasala (1977/78) and Turku (1975/76). The fungus grew and was an extremely effective cabbage pathogen at temperatures of $5^{\circ} \mathrm{C}$ or more, although at $0^{\circ} \mathrm{C}$ it grew as slowly as $P$. lingam (Fig. 5).

Strongly-growing, white mycelia, which had clamp connections but no spores or conidia in the hypha, were found in $15 \%$ of the cabbages in Viikki in 1978/79 and in $4 \%$ in Jyväskylä in 1977/78. Solid, but not hard, initially light yellow-brown, transparent, later on dark brown sclerotia, $0.5-1.5 \mathrm{~mm}$ in diameter, grew in large numbers (Fig. 7a) over the mycelia. The fungus penetrated into the heart of the cabbage heads and rapidly decomposed the cabbage tissue. The cabbages were eventually completely covered by the fungus and spoilt (Fig. 7b). Despite repeated attempts to make transfers of this otherwise unknown species of fungus, it did not grow on any of the most common media (PDA, corn meal agar, malt extract) and evidently could only grow on living cabbages. The same fungus was found on two leeks in Viikki in 1980.

In addition to the above-mentioned fungi, a number of other fungi were found on the stored cabbages which did not, however, cause any damage to the cabbages. These fungi were either found in further cultures, on the outermost partly-desiccated leaves or else less than five times from individual cabbages during the study period. The following fungi were identified: Acremoniella atra (Corda) Sacc., Alternaria brassicae (Berk.) Sacc., Alternaria tenuis Auct.; Aspergillus spp., Cladosporium spp., 

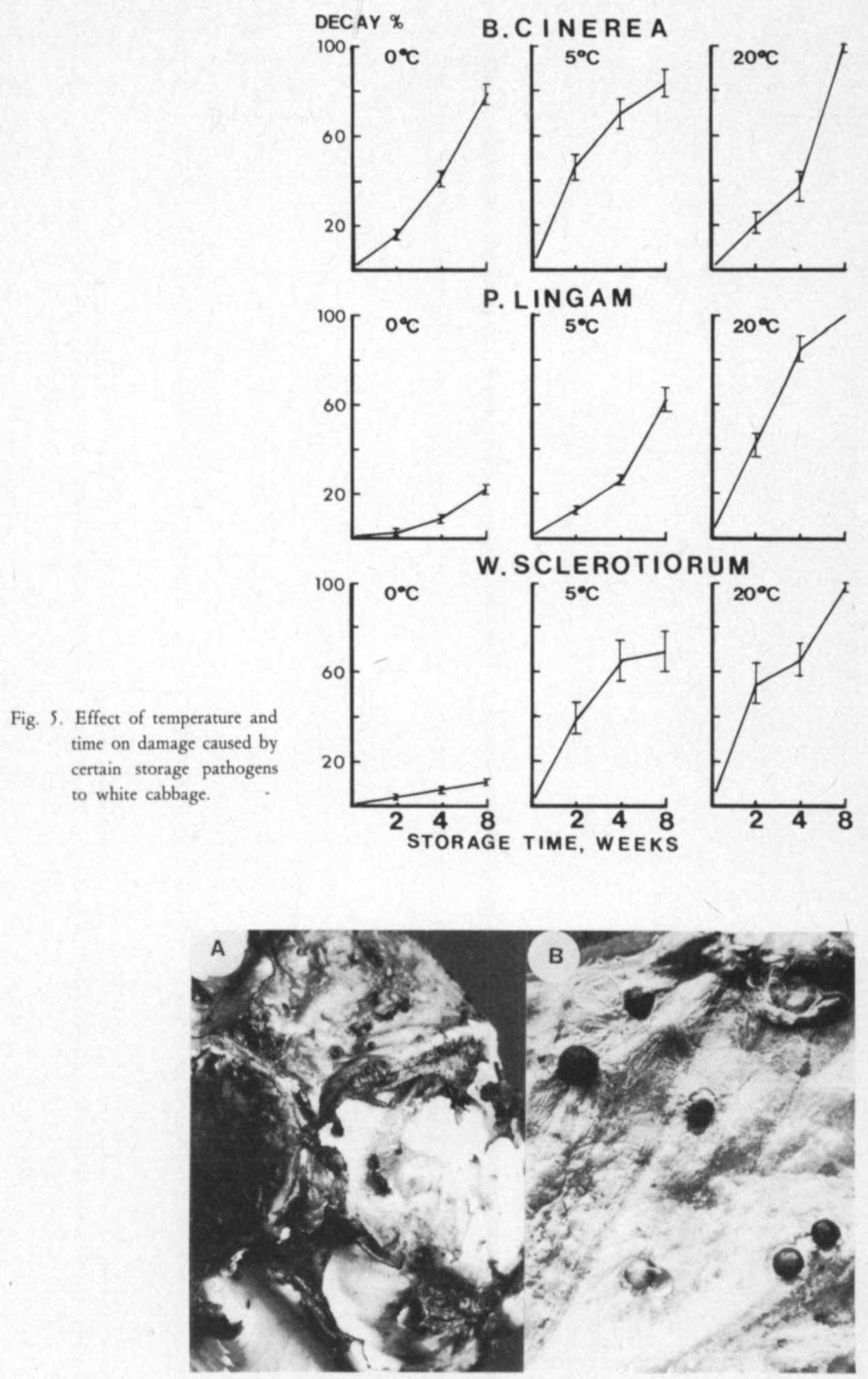

Fig. 6. A cabbage (a) spoilt by Typbula brassicae and (b) sclerotia on the surface of a cabbage head. 

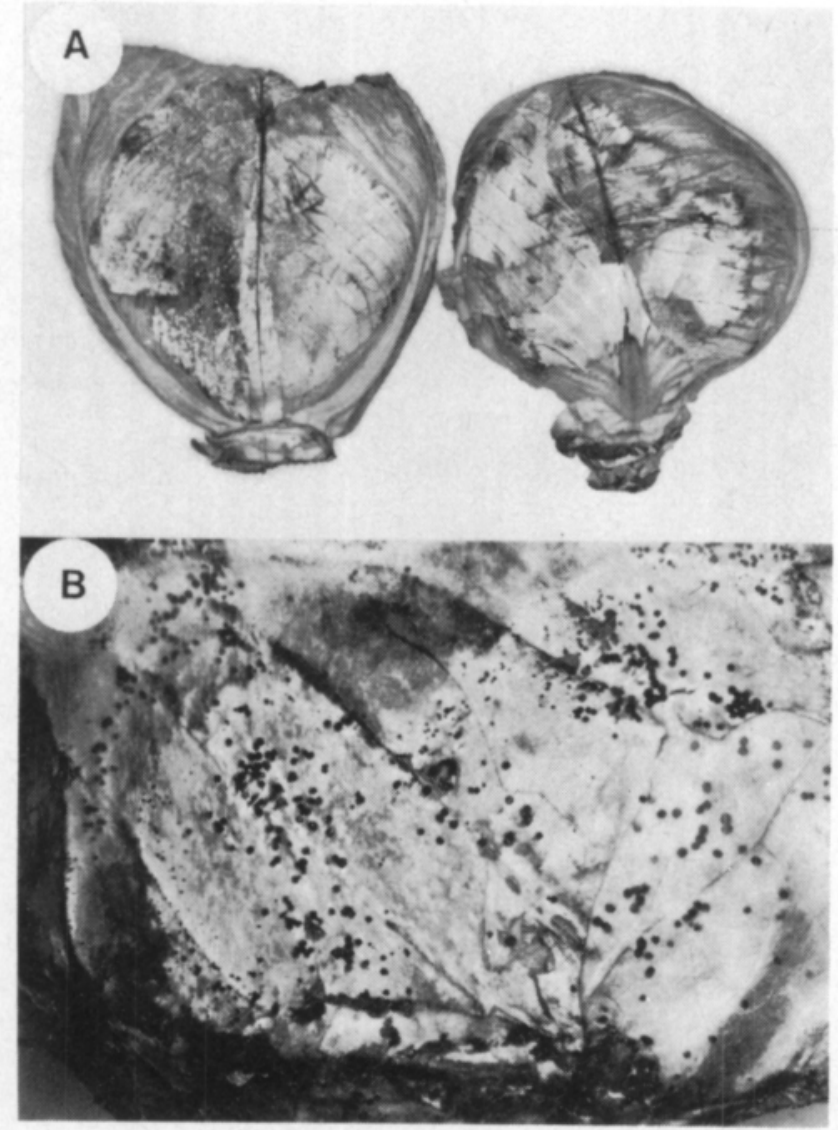

Fig. 7. A cabbage (a) spoilt by an unknown Basidiomycetes which grew at low temperatures, and (b) mycelium and sclerotia of the fungus.

\section{MERCHANTABLE \%}

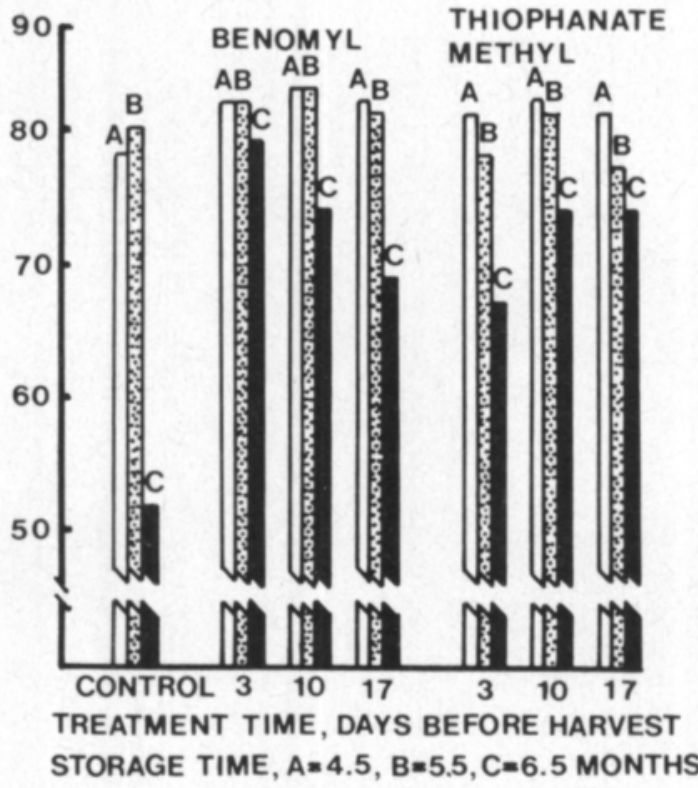

Fig. 8 Effect of spraying with fungicides during the growing season on the merchantability of stored cabbages in Viikki 1975/76. 
Fig. 9. Effect of spraying with Benomyl on the degree of $B$. cinerea infection of cabbages after 6 months storage in 1976/77. a = spraying 14 days before harvesting, $b=$ untreated.

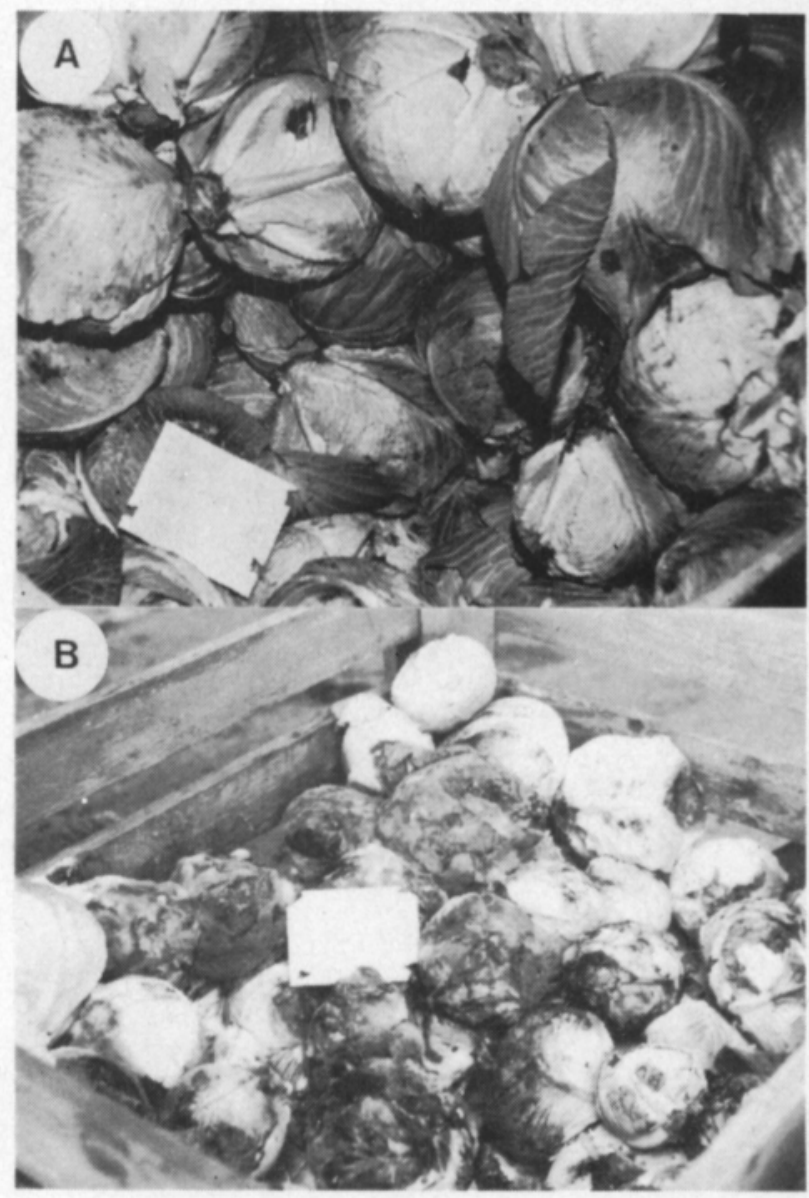

Chrysosporium sp., Fusarium spp., Gliocladium spp., Gliomastix sp., Mucor sp., Penicillium spp., Phytophthora sp., Rbizoctonia spp., Ulocladium consortiale Simmons, and Verticillium spp.

3.2. Control of storage pathogens during the growing season by means of fungicide treatment

\subsubsection{Effect of treatments on Botrytis cinerea and storage losses}

Spraying with fungicides during the growing season, $1-2$ weeks before harvesting, significantly or highly-significantly decreased the incidence of $B$. cinerea on the cabbages in all 11 experiments during the period 1976/77-1979/80 (Tables 1 and 2). The mean B. cinerea abundance on cabbages treated with either benomyl or thiophanatemethyl was less than one in almost all the experiments. In such cases, the damage caused by the pathogen could only be seen upon careful examination of the cabbages (Fig. 9a). The mean B. cinerea abundance on untreated cabbages was in all cases at least 2 or more, often 3-4.5, when there were extensive areas spoilt by the fungus in almost all the cabbages (Fig. 9b).

Sprayings carried out during the growing season significantly reduced the cleaning losses, i.e. increased the number of marketable cabbages at the end of the 
Table 1. Effect of spraying carried out during the growing season on storage losses and occurrence of Botrytis cinerea on cabbage during 1976/77-1978/79.

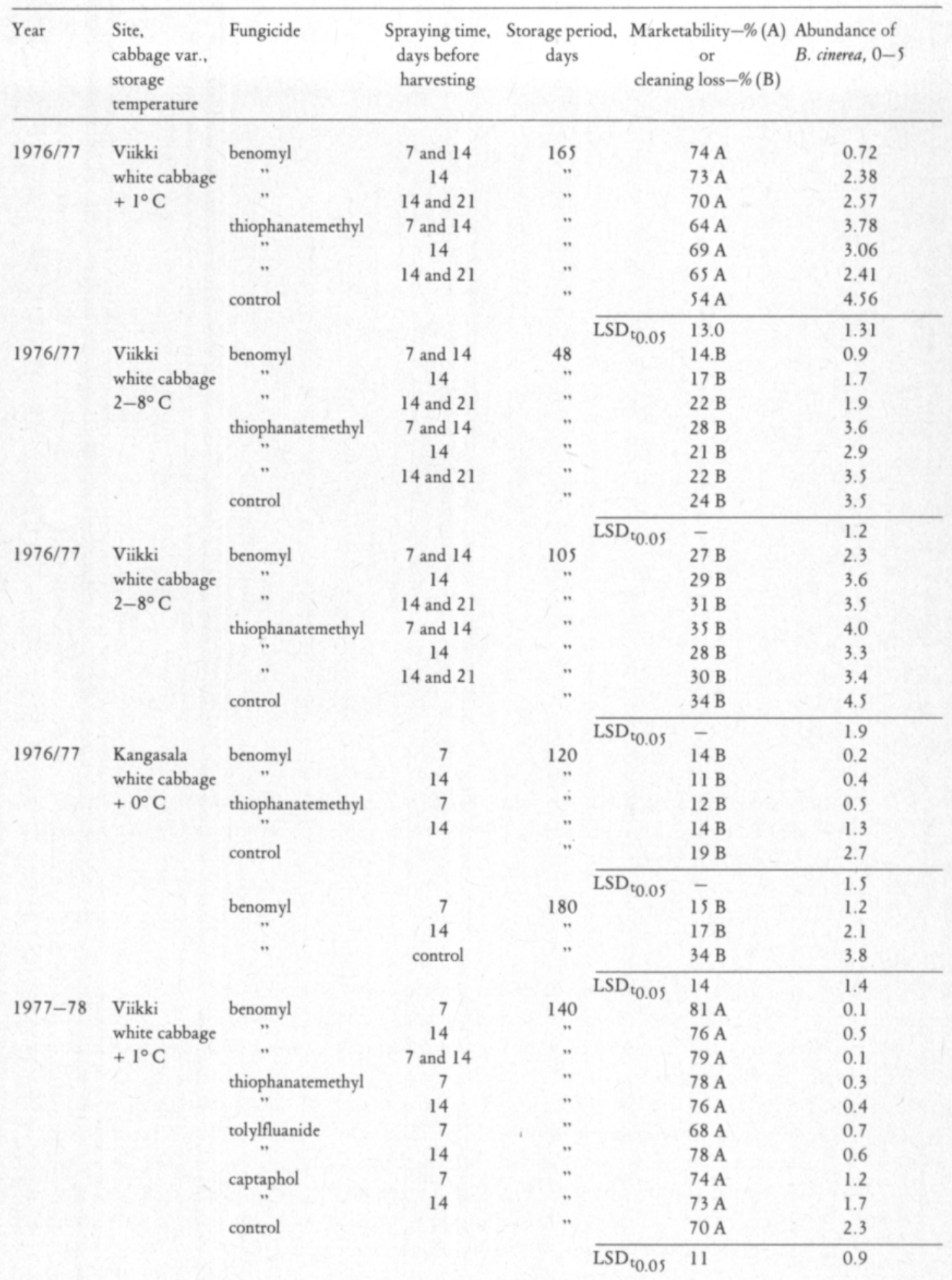


Table 1. Continued

\begin{tabular}{|c|c|c|c|c|c|c|c|}
\hline $1977-78$ & $\begin{array}{l}\text { Viikki } \\
\text { red cabbage } \\
+1^{\circ} \mathrm{C}\end{array}$ & $\begin{array}{c}\text { benomyl } \\
\text { control }\end{array}$ & $\begin{array}{c}7 \\
14 \\
7 \text { and } 14\end{array}$ & $\begin{array}{r}170 \\
" \\
" \\
"\end{array}$ & & $\begin{array}{l}77 \mathrm{~A} \\
77 \mathrm{~A} \\
78 \mathrm{~A} \\
71 \mathrm{~A}\end{array}$ & $\begin{array}{l}0.6 \\
0.5 \\
0.7 \\
1.6\end{array}$ \\
\hline $1977 / 78$ & $\begin{array}{l}\text { Kangasala } \\
\text { white cabbage } \\
+0^{\circ} \mathrm{C}\end{array}$ & $\begin{array}{l}\text { benomyl } \\
\text { thiophanatemethyl } \\
\text { control }\end{array}$ & $\begin{array}{c}7 \\
7 \text { and } 14 \\
14 \\
7\end{array}$ & $\begin{array}{c}144 \\
" \\
" \\
" \\
"\end{array}$ & $\mathrm{LSD}_{t_{0.05}}$ & $\begin{array}{l}7 \\
10 \mathrm{~B} \\
8 \mathrm{~B} \\
7 \mathrm{~B} \\
7 \mathrm{~B} \\
24 \mathrm{~B}\end{array}$ & $\begin{array}{l}0.6 \\
0.6 \\
0.2 \\
0.7 \\
0.7 \\
1.4\end{array}$ \\
\hline $1977 / 78$ & $\begin{array}{l}\text { Jyväskylä } \\
\text { white cabbage } \\
-0^{\circ} \mathrm{C}\end{array}$ & $\begin{array}{c}\text { benomyl } \\
\text { control }\end{array}$ & $\begin{array}{c}7 \\
14 \\
7 \text { and } 14\end{array}$ & $\begin{array}{c}154 \\
" " \\
" \\
"\end{array}$ & $\mathrm{LSD}_{\mathrm{t}_{0.05}}$ & $\begin{array}{l}7 \\
17 \mathrm{~B} \\
11 \mathrm{~B} \\
16 \mathrm{~B} \\
33 \mathrm{~B}\end{array}$ & $\begin{array}{l}0.4 \\
0.6 \\
0.2 \\
0.4 \\
2.0\end{array}$ \\
\hline $1977 / 78$ & $\begin{array}{l}\text { Jyvãskylä } \\
\text { red cabbage } \\
-0^{\circ} \mathrm{C}\end{array}$ & $\begin{array}{c}\text { benomyl } \\
\text { control }\end{array}$ & $\begin{array}{c}7 \\
14 \\
7 \text { and } 14\end{array}$ & $\begin{array}{r}169 \\
" \\
" \\
"\end{array}$ & $\mathrm{LSD}_{\mathrm{t}_{0.05}}$ & $\begin{array}{l}10 \\
24 \mathrm{~B} \\
21 \mathrm{~B} \\
19 \mathrm{~B} \\
43 \mathrm{~B}\end{array}$ & $\begin{array}{l}0.7 \\
0.1 \\
0.1 \\
0.4 \\
3.1\end{array}$ \\
\hline $1978 / 79$ & $\begin{array}{l}\text { Viikki } \\
\text { white cabbage } \\
+1^{\circ} \mathrm{C}\end{array}$ & $\begin{array}{l}\text { benomyl } \\
\text { thiophanatemethyl } \\
\text { control }\end{array}$ & $\begin{array}{c}7 \\
14 \\
7 \text { and } 14 \\
7 \\
14 \\
7 \text { and } 14\end{array}$ & $\begin{array}{r}175 \\
" \\
" \\
" \\
" \\
"\end{array}$ & $\mathrm{LSD}_{\mathrm{t}_{0.05}}$ & $\begin{array}{l}14 \\
77 \mathrm{~A} \\
73 \mathrm{~A} \\
74 \mathrm{~A} \\
76 \mathrm{~A} \\
79 \mathrm{~A} \\
80 \mathrm{~A} \\
66 \mathrm{~A}\end{array}$ & $\begin{array}{l}1.0 \\
0.8 \\
1.5 \\
1.3 \\
1.1 \\
1.8 \\
0.9 \\
2.7\end{array}$ \\
\hline $1978 / 79$ & $\begin{array}{l}\text { Viikki } \\
\text { red cabbage } \\
+1^{\circ} \mathrm{C}\end{array}$ & $\begin{array}{l}\text { benomyl } \\
\text { thiophanatemethyl } \\
\text { control }\end{array}$ & $\begin{array}{c}7 \\
14 \\
7 \text { and } 14 \\
7 \\
14 \\
7 \text { and } 14\end{array}$ & $\begin{array}{c}162 \\
" \\
" \\
" \\
" \\
" \\
"\end{array}$ & $\mathrm{LSD}_{\mathrm{t}_{0.05}}$ & $\begin{array}{l}12 \\
67 \mathrm{~A} \\
68 \mathrm{~A} \\
68 \mathrm{~A} \\
60 \mathrm{~A} \\
66 \mathrm{~A} \\
63 \mathrm{~A} \\
60 \mathrm{~A}\end{array}$ & $\begin{array}{l}1.6 \\
2.8 \\
3.0 \\
2.8 \\
3.5 \\
3.9 \\
3.1 \\
4.5\end{array}$ \\
\hline & & & & & $\mathrm{LSD}_{t_{0.05}}$ & - & 1.4 \\
\hline
\end{tabular}

Table 2. Effect of amount of water used in spraying benomyl on storage losses and abundance of Botrytis cinerea on white cabbage. Stored for 163 days at $1^{\circ} \mathrm{C}$, Viikki $1979 / 80$.

\begin{tabular}{lcccccc}
\hline & Control & \multicolumn{3}{c}{ Water 1/ha } & F-value \\
\cline { 3 - 6 } & & 200 & 400 & 1000 & 2000 & \\
\hline $\begin{array}{l}\text { Marketability-\% } \\
\begin{array}{l}\text { Abundance of } B \text {. cinerea, } \\
0-5\end{array}\end{array}$ & 46.8 & 72.1 & 69.9 & 69.6 & 69.6 & $6.1^{\mathbf{x x x}}$ \\
\hline
\end{tabular}


storage period throughout the course of the experiments (Tables 1, 2, Fig. 8). The spraying date had no effect on the degree of fungus infection. The storage losses decreased in the different experiments by $8-25 \%$, on the average by $16 \%$. The benefit gained through spraying increased as the duration of the storage period was increased (Table 1, Fig. 8). In the case of storage for four months in a cold store or cellar, spraying was of no benefit in reducing the amount of infection and the increase in the marketability of the cabbages was only negligible. The different amounts of water used in applying the fungicides had no effect on the control of $B$. cinerea (Table 2).

\subsubsection{Effect of the treatments on other fungi}

The proportion of the losses caused by other storage pathogens was so small, that the effect of sprayings during the growing season on the incidence of these fungi could not be reliably determined.

In those experiments where there was much Plenodomus lingam, Typhula brassicae or the unidentified fungus described on p. 217, the treatments had no apparent effect on the abundance of these fungi.

\subsubsection{Residues}

The benomyl or thiophanatemethyl sprayed on the cabbages two weeks before harvesting were no longer present as residues on the cabbage plants at harvesting.

\section{Discussion}

The type of storage pathogens found on cabbages in Finland are to a great extent the samic as those found in other countries. The numbers of different pathogenic fungi differ, however. In countries like Norway and Great Britain with a maritime climate where the weather conditions during harvesting are usually wetter and warmer than in Finland, Alternaria brassicicola Wiltshire ond Phytopthora porri Foister are, in addition to Botrytis cinerea Pers. ex Fr., serious pathogenic fungi (SEMB 1968, KEAR et al. 1977). Since cabbage heads have to be stored in Finland for a considerably long time, 5-7 months, mechanicallyrefrigerated stores only can be used for such purposes. As the temperature in such stores is close to $0^{\circ} \mathrm{C}$, or slightly above, $B$. cinerea is almost the only storage fungus of any importance. In many other studies the damage caused by this fungus has been found to be as extensive as that in this study (STRUC and CRUTZ 1972, BROWN et al. 1975, GEESON and ROBINSON 1975, BOCHOW et al. 1976, LOCHART 1976, KEAR et al. 1977, SEIDEL and BARESEL 1978).

Unlike the type of storage pathogens found on cabbages in other countries, Typhula brassicae (Berg. ex Fr.) Vang occurs quite commonly in Finland. It has been reported to be a common winter pathogen of rape in Finland (HAAVISTO 1956, VALLE 1958) and LIRO (1924) considers it to be a storage pathogen of cabbage. VANG (1945) considers this fungus to be synomynous with $T$. betae Rostr., $T$. gyrans (Botsch) Fr. and T. variabilis Riess. Damage caused by $T$. brassicae started to appear in the stores after storage periods of 6 and 7 months. Such long storage 
periods are not normally used for cabbage in other countries and hence it is quite understandable that it is not mentioned as a storage pathogen elsewhere.

The external appearance and symptoms of the disease caused by the fungus which occurred on cabbages in Viikki in 1977/78 and in Jyväskylä in 1978/79 did not correspond to any pathogen of cabbage which has been reported in the literature. As it was not possible to cultivate the fungus on any growth medium and as the fungus itself was itself always destroyed by the time the cabbage was completely spoilt, it was not possible to carry out any other attempts at identification. Owing to the clamp connection formation of the hypha and its ability to grow at a low temperature of $0^{\circ} \mathrm{C}$, this fungus is denoted in the figure legends as "an unidentified Basidiomycete which grows at low temperatures". This fungus appears to be at least as severe a storage pathogen of cabbages as $B$. cinerea at low temperatures. It seems, however, that it will remain a problem of cabbage growers, probably in field cultivations only. The fungus has not occurred in Viikki since the experiments were transferred to a new field plot. The two infected leeks which were found in Viikki in 1980 had also been grown on the same field as the infected cabbages. In Jyväskylä, cabbages had been grown on the same field plot for 15 years.

On the basis of the experiments carried out in different areas with both red and white cabbage, it appears that the $B$. cinerea levels on stored cabbages can be significantly reduced, or almost completely controlled, by spraying the cabbage plants with fungicide $1-2$ weeks before harvesting. This type of control method, which was approved for commercial use in 1979 and consists of spraying with benomyl or thiophanatemethyl two weeks before harvesting in the case of red or white cabbages which are to be stored for a considerable period of time, indirectly showed that stored cabbages become infected already during the growing season. However, it was not possible in this study to determine, to any degree of certainty, whether the fungus had already penetrated the cabbage tissues during the growing season or whether it was merely on the surface of the crop. According to YODER and WHALEN (1975), B. cinerea can penetrate cabbage tissue if there is any cabbage sap, sugar solution or soil particles on the surface of the leaves. In the experiments carried out here, $B$. cinerea was visible on the outermost leaves of wellmatured cabbages at harvesting time on a number of occasions. This would indicate that the tissue of at least some of the cabbages had become infected when they were still growing in the field. $B$. cinerea did not presumably spread to any appreciable extent just before harvesting because the spraying date had no significant effect on the $B$. cinerea levels, and treatment carried out during harvesting had no subsequent effect on leaves infected with $B$. cinerea. In the study carried out by CHASTAGNER et al. (1978) on aerial-borne infection of $B$. cinerea, high humidity and low temperatures, which is usually the case in Finland at harvesting time, were found to reduce or inhibit the aerial dissemination of the conidia of this fungus. This supports the conclusion made in this study about the time at which $B$. cinerea infects cabbages.

The numbers and levels of $B$. cinerea, the storage losses caused by it, the interdependance between these parameters, and the only slight risk of the disease spreading from one individual cabbage to another during storage, all obviously provide good possibilities for forecasting, at a fairly early stage, the storability of cabbage in long-term storage. The losses caused by evaporation and other physiological factors remain fairly constant in good stores, i.e. about $0.05-0.1$ 
$\% /$ day (SUHONEN 1969). The losses caused by storage pathogens in Finland are in practice only dependant on $B$. cinerea levels. When the actual or relative level of this fungus is determined before the damage caused by it starts to steeply increase in February, the probable storage losses can be reliably estimated and suitable plans made about the storage time and selling date of different cabbage lots even. The $B$. cinerea- $\%$ can be determined either directly in the store or else from sample lots taken from the store, which have been kept under conditions, from the point of view of the fungal host, which are as favourable as possible for the growth of the fungus, e.g. about $+5^{\circ} \mathrm{C}$. Further studies will be carried out along this line in Viikki in order to develop methods for forecasting the storability of cabbages.

Acknowledgements: The funds provided over a period of three years by the Cultural Fund of Finland have made this study possible. Prof. Eeva Tapio has given much advice and support during the course of the experiments. Miss Lahja Pesonen, Mr. Tauno Koivunen, Mr. Pentti Heinänen and Mr. Eero Miettinen, M. Sc., all from the Department of Plant Pathology, have assisted with practical aspects of the studies and the collation of the results. Steward Erkki Luotonen from Kangasala and gardener Juhani Tahvonen from Jyväskylä have provided the plants and storage space required in the experiments. I would like to express my sincere thanks to all the above parties and to others who have provided advice and support.

\section{References}

ADAIR, G. N. 1971. Influence of controlled atmosphere storage condition on cabbage postharvest decay fungi. Pl. Dis. Rep. 55: 864-868.

BOCHOW, H., HOFFMANN, K., KUMPF, S. \& MEINL, G. 1970. Über das Anfällingkeitsverhalten verschiedener Kopfkohlsorten während der Lagerung gegenüber Botrytis cinerea Pers. Arch. Phytopath. und Pfl. schutz 12: 261-273.

BROWN, A. C., KEAR, R. W. \& SYMONS, J. P. 1975. Fungicidal control of Botrytis cinerea on cold-stored white cabbage. Proc. 8th Brit. Insectic. Fungic. Conf. 1975: 339-346.

CHASTAGNER, G. A., OGAWA, J. M. \& MANJI, B. T. 1978. Dispersal of conidia of Botrytis cinerea in tomato fields. Phytopath. 68: 1172-1176.

DOMSCH, K. H. \& GAMS, W. 1970. Pilze aus Agrarböden. 222 p. Stuttgart.

ELLIS, M. B. \& WALLER, M. J. 1974. CMI Descriptions of pathogenic fungi and bacteria No 431.

FOLLSTAD, M. N. 1966. Mycelial growth rate and sporulation of Alternaria tenuis, Botrytis cinerea, Cladosporium berbarum and Rbizopus stolonifer in low-oxygen atmospheres. Phytopath. 56: 10981099.

GEESON, J. D. 1976. Storage rot of white cabbage caused by Pbytopbtbora porri. Pl. Path. $25: 115-116$.

- \& BROWNE, K. M. 1979. Effect of post-harvest fungicide drenches on stored winter white cabbage. Pl. Path. 28: 161-168.

- \& ROBINSON, J. E. 1975. Damage will mean trouble in store. Commercial Grower 4147: 12451246.

HAAVISTO, M. 1956. Typhula betae Rostr. on winter turniprape. J. Scient. Agric. Soc. Finl. 28: $105-108$.

HENDERSON, M. P. 1918. The blackleg disease of cabbage caused by Pboma lingam (Tode) Desmaz. Phytopath. 8: 379-431.

KEAR, R. W., WILliaMS, D. J. \& STEVENS, C. C. 1977. The effect of iprodione on the fungal deterrioration of stored white cabbage. Proc. 9th Brit. Insectic. Fungic. Conf. 1977: 189-195.

LIRO, J. I. 1924. Tuhosienet. 405 p. Helsinki.

LOCHART, C. L. 1976. Reduncing disease losses in stored cabbage. Can. Agric. 21: 9-10.

SEIDEL, M. \& BARESEL, F. 1978. Der Einsatz eines Spritztunnels zur Behandlung von Kopfkohl gegen Lagerfäulen in der LPG "Am Meer des Friendens" Elmerhorst. Nachr. bl. Pfl. schutzd. in der DDR 32: 55-56.

SEMB, L. 1968. Algeropp som årsak til rote på laget Hwitkål. Gartneryrket 58: 873-876. 
STRUC, P. \& CRUTZ, E. M. 1972. Erfolgreiche Lagerung von Kopfkohl. Gartenb. 19: 201-202.

SUHONEN, I. 1969. On the storage life of white cabbage in refrigerated stores. Acta Agr. Scand. 19: 1832.

- 1980. Vihannesviljely avomaalla. 164 p. Helsinki.

WALKER, J. C., CARSON, R. H. \& TAYLOR, A. L. 1958. Disease of cabbage and related plants. U.S. Dep. Agric. Handb. No. 144.

VALLE, E. 1958. Syysrypsin talvituhosienistä Suomessa. Laudatur-työ. 100 p. Helsinki.

VANG, J. 1945. Typbula species on agricultural plants in Denmark. Medd. Plantepatologisk Afd. 28: 1-46.

WELLMAN, F. L. 1932. Rbizoctonia -bottom rot and heat rot of cabbage. J. Agr. Res. 45: 461-469.

VOGEL, G. \& NEUBERT, P. 1964. Ergebnisse bei der Anwendung von Phomasen (Pentaclornitrobenzol) zur Kopkohllagerung. Gartenb. 11: 205-208.

YLÄTALO, M. 1980. Vihanneksia on varastoituna runsaasti. Puutarha-Uutiset 32: 1164-1165.

YODER, O. C. \& WHALEN, M. L. 1975. Factors affecting post-harvested infection of stored cabbage tissue by Botrytis cinerea. Can. J. Bot. 53: 691-699.

Ms received September 4, 1981.

\section{SELOSTUS}

\section{Keräkaalin varastotaudit ja niiden torjunta}

\section{Risto Tahvonen}

\section{Helsingin yliopiston kasvipatologian laitos, 00710 Helsinki 71}

Vuosina 1975-80 tutkittiin Helsingin yliopiston kasvipatologian laitoksella kaalin varastotauteja ja niiden torjuntamahdollisuuksia. Kaalin varastotaudit ovat olleet näihin päiviin asti viljelyn taloudellisesti merkittãvin haittatekijä, johon ei ole ollut käytössä tyydyttäviä torjuntamenetelmiä. Myös nykyaikaisissa kylmävarastoissa, joissa varasto-olosuhteet ovat olleet optimaalliset, ovat varastotaudit tehneet merkittävää tuhoa. Kaalin varastosienilajiston selvittämiseksi haettiin näytteitä Turun, Kangasalan ja Jyvāskylän alueiden viljelijöiltä. Lisāksi Viikissā, Kangasalla ja Jyvāskylässā perustetuista kokeista tutkittiin sienilajistoa. Varastotautien torjumiseksi perustettiin useita kokeita, joissa ennen sadonkorjuuta tehtiin torjunta-ainekäsittelyjä tuotteiden mukana kulkeutuvien sienien torjumiseksi.

Yleinen harmaahome (Botytis cinerea Pers. ex Fr.) oli yleisin ja taloudellisesti merkittävin kaalin varastotauti, joka esiintyi kaikissa varastoissa 40-100\%:ssa, useimmiten 60-80\%:ssa kaaleista. Kauppakunnostuksessa syntyneiden tappioiden suuruus oli suoraan riippuvainen harmaahomeen määrästā. Yli S kuukautta kestävässä varastoinnissa terveiden kaalien kauppakunnostustappiot olivat $10-20 \%$, mutta vastaavilla voimakkaasti harmaahomeen saastuttamilla kaaleilla kunnostustappiot nousivat 30-50\%:iin. Yleinen harmaahome saastutti kaalit jo pellolla kasvuk irden aikana joko pinnallisena tai uloimpiin päällyslehtiin tunkeutuneena. Lähellä sadonkorjuuaikaa ja $s^{\cdots}$ yhteydessä ei enää tapahtunut merkittävää saastumista. Varastoinnin aikana tauti levisi vain kosketuksen kaurta sairaasta terveeseen kaaliin, mutta ei lainkaan ilman kautta.

Muilla varastosienillä ei ollut niin suurta merkitystä, että niiden aiheuttamista tuhoista voitaisiin antaa keskimääräisiä \%-lukuja. Vain yksittāisissä, paikallisissa tapauksissa tai joinain vuosina pahkulahome (Typbula brassicae (Berk. ex Fr.) Vang), yleinen pahkahome (Whetzelinia sclerotiorum (Lib.) Korf \& Dumont) ja ristikukkaisten mustalaikkusieni (Alternaria brassicicola Wiltshire) olivat tuhon aiheuttajina. Näiden lisäksi tavattiin kahdesta paikasta toistaiseksi tuntematon, kantasieniin kuuluva sieni, joka kasvoi ja pilasi voimakkaasti kaaleja $0^{\circ} \mathrm{C}: \mathrm{n}$ jäähdytysvarastossa.

Yleinen harmaahome voittiin torjua varastoidulta kaalilta lähes täydellisesti tai rajoittaa sen runsautta merkittävästi ruiskuttamalla kaalit 1-2 viikkoa ennen sadonkorjuuta Benlate- (benomyyli) tai Topsin $\mathrm{M}$ (tiofanaattimetyyli)-kauppavalmisteella. Kaalin varastointitappiot vähenivãt merkitsevāsti kãsittelyjen ansiosta. Tämã menetelmä kaalin varastotautien torjumiseksi on hyväksytty viljelijäkäyttöön v. 1979 siten, ettã ruiskutukset ovat sallittuja pitkään varastoitaville kaaleille 2 viikkoa ennen sadonkorjuuta. 